\title{
(조) \\ U.S. GEOLOGICAL SURVEY GROUND-WATER STUDIES IN SOUTH CAROLINA
}

\section{GROUND-WATER ISSUES}

Fresh ground water is available in most of South Carolina. Although it provides only about 4 percent of total water used in the State, it serves 42 percent of the population, or about 1.33 million people. Most large withdrawals of ground water are obtained from coastal plain aquifers in the southeastern twothirds of the State. Of all ground water used, 40 percent is for public supply, 28 percent for rural domestic supplies, 22 percent for industry, 7 percent for irrigation, and 3 percent for watering livestock. The major issues related to ground water in South Carolina are:

- Contamination caused by disposal of wastes. South Carolina imports low-level radioactive waste and hazardous waste, and generates many types of wastes, including high-level radioactive. Contamination by petroleum products, organic solvents, metals, and radioactive substances has occurred at a number of industrial sites,

- Saltwater intrusion caused by reversal of ground-water flow patterns and declining water levels resulting from heavy pumping near the coast, and

- Naturally high concentrations of sodium, fluoride, iron, and dissolved solids in some areas.

\section{U.S. GEOLOGICAL SURVEY PROGRAMS}

The U.S. Geological Survey (USGS), established in 1879, is the principal source of scientific and technical expertise in the earth sciences within the Federal government. USGS activities include research and services in the fields of geology, hydrology, and cartography. The mission of the Water Resources Division of the USGS is to develop and disseminate scientific information on the Nation's water resources. The activities of the Water Resources Division in South Carolina are conducted by scientists, technicians, and support staff in offices in Columbia, Myrtle Beach, Aiken, and Beaufort.

Hydrologic-data stations are maintained at selected locations throughout South Carolina to obtain data on stream discharge and stage, reservoir storage, ground-water levels, and the quality of surface and ground water. Water-resources data are stored in the USGS National Water Data Storage and Retrieval System data base. These data are used by water planners and others involved in decisions that affect South Carolina's water resources.

During 1987, the USGS, in cooperation with the South Carolina Water Resources Commission, maintained a network of about 40 observation wells in South Carolina to monitor fluctuations in water levels. Water-level measurements from wells are used to monitor ground-water trends; however, they need to be integrated with other observations and ground-water investigations to be most relevant and useful.

The USGS has conducted more than 80 hydrologic investigations in South Carolina. During fiscal year 1987, the USGS entered into cooperative or cost-sharing agreements with 25 Federal, State, and local agencies involving 18 hydrologic investigations in South Carolina; six investigations included studies of ground-water quantity and quality. These investigations will provide information needed to answer hydrologic questions that are specific to the State's principal ground-water issues. Some of these investigations also will provide information on statewide, multistate, and national hydrologic problems. Three examples of ground-water studies by the USGS that address specific ground-water issues in South Carolina are discussed in the following sections.

\section{Hazardous-Waste Landfill Near Pinewood}

More than 1 billion pounds of hazardous waste are buried in a landfill, one of two active hazardous-waste landfills in the Southeast. South Carolina's largest reservoir, Lake Marion, is 1,000 feet from the landfill. The USGS, in cooperation with the South Carolina Public Service Authority, the operators of the reservoir, is investigating surface- and ground-water flow

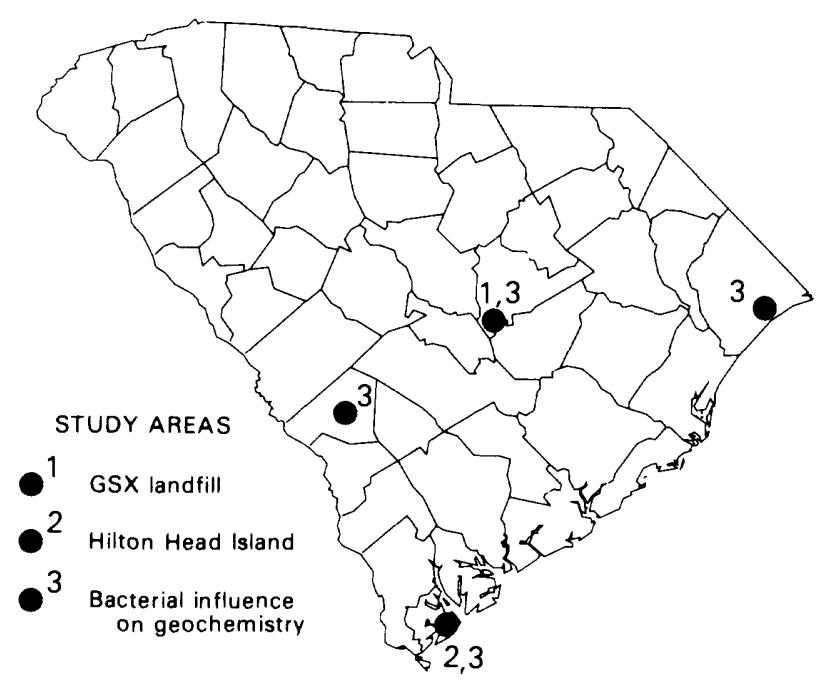


near the landfill to determine the potential for contamination of Lake Marion and underlying aquifers. Results of the project will be used by the cooperator to design a monitoring program to detect degradation of surface-water quality, and to help formulate policy toward continued operation or expansion of the landfill. Results also will be used by personnel of the landfill-operating company to improve their understanding of the hydrology at their site. State legislators have discussed with the company the possibility of erecting hydrologic barriers at potential locations determined from study results. Finally, results of this study also will be used by the South Carolina Department of Health and Environmental Control in its regulatory programs.

\section{Saltwater Intrusion Under Hilton Head Island}

Pumping of ground water near Savannah, Ga., has reversed the direction of ground-water flow under Hilton Head Island and created the potential for intrusion of saltwater into the upper Floridan aquifer, the source of drinking water for Hilton Head. The USGS, in cooperation with the South Carolina Water Resources Commission, has determined the location and nature of brackish and saltwater zones in the aquifer near Hilton Head. The velocity of saltwater encroachment toward Hilton Head has been calculated, based on computer simulations of flow and solute transport in the aquifer. Much of the information used in this study was gained from nine test wells drilled offshore into submarine sediments where the saltwater-freshwater interface is currently located. Results of the study will be used by the cooperator and by public service districts on Hilton Head to design strategies that may use combinations of pumping and injection to delay the encroachment of saltwater.

\section{Bacterial Influence on Geochemistry of Coastal Plain Aquifers}

Until recently, ground water generally was considered to be devoid of life forms. The USGS has found that numerous strains of common soil bacteria exist in deep aquifers in the coastal plain (southeastern two-thirds) of South Carolina, and that bacterial activity helps to answer some of the questions about water quality and aquifer properties. A practical application of this research is a project in cooperation with the U.S. Navy to determine the potential for bacteria to decompose jet fuel in ground water at the Defense Fuel Supply Point in North Charleston.

\section{GROUND-WATER MANAGEMENT}

Two principal State agencies are responsible for ground-water management in South Carolina. The South Carolina Water Resources Commission evaluates water resources and monitors declining water levels. The South Carolina Department of Health and Environmental Control regulates waste disposal and groundwater protection, and monitors water quality. Both agencies use ground-water data and the results of ground-water investigations conducted by the USGS. During fiscal year 1988, the following Federal, State, and local agencies entered into interagency or cooperative cost-sharing agreements with the USGS to conduct ground-water investigations in South Carolina:

South Carolina Department of Health and Environmental Control South Carolina Geological Survey

South Carolina Public Service Authority

South Carolina Water Resources Commission

U.S. Department of Energy

U.S. Navy

\section{SELECTED REFERENCES}

Chapelle, F.H., Morris, J.T., McMahon, P.B., and Zelibor, J.L., 1988, Bacterial metabolism and the delta-13 C composition of ground water, Floridan aquifer system, South Carolina: Geology, v. 16, no. 2, p. 117-121.

U.S. Geological Survey, 1985, National Water Summary 1984Hydrologic events, selected water-quality trends, and ground-water resources: U.S. Geological Survey Water-Supply Paper 2275, 467 p.

Information on technical reports and data related to ground water in South Carolina can be obtained from:

\author{
District Chief \\ U.S. Geological Survey \\ Water Resources Division \\ 1835 Assembly Street, Suite 677A \\ Columbia, South Carolina 29201 \\ Director \\ South Carolina Water Resources Commission \\ P.O. Box 4440 \\ Columbia, South Carolina 29240
}

Open-File Report 88-154

Glenn G. Patterson, 1988 